\title{
AN HISTORICAL REVIEW OF PLANS FOR PRESIDENTIAL STAFFING
}

\author{
Edward H. HoBbs*
}

The President of the United States has not always been the busy man we know him to be today. As a matter of fact, prior to the First World War, little or no interest was shown in equipping him with administrative staff facilities to mitigate the burdens of his office; but after I9I8, the general significance of presidential administrative power became more manifest, and, with this realization, a few prescient scholars began thinking in terms of shoring up the managerial responsibilities of the President. Roughly from the beginning of the nineteen-twenties to the present, solutions to presidential staff problems have been sought by many students of the national executive. Since the middle nineteen-thirties, when President Franklin D. Roosevelt's Committee on Administrative Management took a long look into this matter, attendant problems have increased in both number and scope. Budgets are bigger, personnel requirements are multiplied, policies that need firming up are more numerous, international and domestic problems clash head-on; yet, the synthesizing force in the national government still must be centered in the office of the President.

The principal purpose of this piece is to examine a variety of proposed plans for organizing presidential staff services that have been devised over the years. Before capsuling the multifarious proposals for propping up the President, it seems appropriate to recall that it was from the work of Messrs. Louis Brownlow, Charles E. Merriam, and Luther Gulick in $1936-37$, as members of the President's Committee on Administrative Management, that a presidential staff institution known as the Executive Office of the President emerged. The Executive Office traces its legal origin to Reorganization Plan No. I of I939 and to Executive Order 8248, September 8, of the same year. ${ }^{1}$ Orginally the Executive Office was comprised of the following divisions: the White House Office, the Bureau of the Budget, the National Resources Planning Board, the Liaison Office for Personnel Management, the Office of Government Reports, and "in the event of a national emergency, or threat of national emergency, such office for emergency management as the President shall determine."

Almost the entire history of the Office can be told through the many administrative reorganizations through which it has been put since 1939. Of the original six divisions, only the White House Office and the Bureau of the Budget still count

* A.B. I943, University of North Carolina; M.A. 1947, University of Alabama; Ph.D. I95I, Harvard University. Professor of Political Science, University of Mississippi; Assistant Director, Bureau of Public Administration; Editor, Public Administration Survey. Author, BeHIND THE President (r954). Contributor to journals in the field of public administration and state and local government.

${ }^{1} 3$ C. F. R. 576 (Supp. 1943). 
today as principal divisions, and they, too, have been shaped and reshaped under the direction of three different Presidents. How well has this staff institution served the President? Answers to this question necessarily are subjective, but the Office has been both generously damned and lauded by competent observers. For example, Professor George Graham of Princeton University a few years ago pointed an accusing finger at the Executive Office on three major counts: "One is lack of internal unity; a second is inadequate contact with staff groups at other levels of authority; and a third is inability to supply adequate positive leadership, certainly in peak periods, perhaps at all times." ${ }^{2}$ These are serous criticisms. In a similar vein, Leonard D. White of the University of Chicago, in reference to the Executive Office, made this terse remark: "The very complex problem of super-departmental coordination had not been solved in 1948 , although it was urgent."3

In 1953 and 1954, as the Eisenhower "team" was learning how to work as a presidential staff with a sense of unity, these comments applied with particular force. Contradictions in administration policies became embarrassingly apparent, and even a friendly press suggested that the "team's" left hand did not know what its right was doing. The evaluations of Graham and White were not flattering to public management in the United States. Legislators and public administrators were still groping in the decade of the forties and fifties for techniques that would assure for the President staff services capable of providing superdepartmental coordination of national policies and that unity of action and advice which the President needs if he is to arrive at final decisions with confidence and without fear of forging policy inconsistencies. Just how impervious and thorny the question of organizing staff services for the President has been for nearly forty years is revealed in the multiplicity of plans that have been developed.

Uncomplimentary reflections upon the performance of the Executive Office are countered somewhat by more sanguine appraisals. Fritz Morstein Marx, of the Bureau of the Budget, American and Howard Universities, wrote: "The Executive Office [of the President] ... . is a relatively new creation-so new that one may marvel at the vitality it has displayed in the test of extraordinary wartime demands upon it, and despite the additional strain of internal transformations." ${ }^{*}$ C. L. Rossiter, four years later, appraised the Executive Office of the President in the following manner:

In sum, the constitutional significance of the Executive Office, as it was originally conceived, and even more positively as it exists today, would seem to be this: It converts the Presidency into an instrument of twentieth century government; it gives the incumbent a sporting chance to stand the strain and fulfill his Constitutional mandate as a one-man branch of our three-part government; it deflates even the most forceful argu-

${ }^{2}$ Graham, The Presidency and the Executive Office of the President, 12 J. Poumcs 591, 621 (1950).

3 Leonard D. White, Introduction to the Study of Public Administration 214 (1939).

-Marx, The Bureau of the Budget: Its Evolution and Present Role, 39 Am. Por. Scr. Rzv. 653, 654 (1945).

${ }^{5}$ Rossiter, The Constitutional Significance of the Executive Office of the President, 43 Am. Por. Scr. REV. 1206, 1214, 1215 (1949). 
ments (e.g., Mr. Herman Finer's) for a plural executive; it assures us that the Presidency, and with it the Constitution of 1787 , will survive the advent of the service state...

... I would even go so far as to suggest that what we have here in embryo are the lineaments of a Presidency not only for the twentieth or twenty-first centuries, but for every century to the end of the Republic.

Luther Gulick of the Institute of Public Administration and former member of the President's Committee on Administrative Management offered a commentary upon the efficacy of the Office after a serious study of national administration during the Second World War. ${ }^{6}$

During the war, the Presidency as such functioned extraordinarily well from every major point of view. Its greatest contribution was its firm stability and dynamic coordinated handling of political leadership, military leadership, international negotiation, and top management of wartime and peacetime agencies of the government, on the foundation of popular consent, freedom and devotion.

A more cautious observation has been tendered by Professor John M. Gaus of Harvard: ${ }^{7}$

Within ten years, the organization of the Executive Office of the President has been much changed; yet it would probably be agreed that valuable experience has been gained, and the central idea that there should be such an institution at all has been profoundly justified. Measures such as these need to simmer long and slowly on the back of the stove before the juices of the various constituents can interpenetrate and produce the most nutritious and delicious result-and during the slow process, opportunity is given for skimming off those elements that have floated to the surface or have otherwise been rejected by the total brew. Those alarmed at excess and dictatorial power, or fearful that the executive may be too weak and harassed to meet the public needs, may take some comfort in this apparently inevitable process of institutional adaption to persistent and subtle modifying forces in American life.

Professional opinion as to the efficaciousness of the Executive Office stands divided.

Many citizens have looked upon the President's job as oppressive and some have offered proposals for strengthening his hand in dealing with his responsibilities. Others have gone further and made recommendations that would solve the problem of the President by abolishing the position. The logic of such recommendations is that since no one man can successfully carry out the presidential job, the executive branch should be revolutionized by setting up a plural executive. However, of the plans propounded by public administrators and other specialists that are more moderate in the tenor of their reform objectives, the following basic recommendations recur:

(I) surround the President with the highest quality executive assistants available,

(2) formalize a systematic network of interdepartmental committees,

(3) establish additional high-policy coordinating units,

(4) create a staff chief to pull the components of the Office itself together, and

(5) convert the Vice President into an executive official.

\footnotetext{
- Luther Gulick, Administrative Refiections from World War II, 76 (i948).
}

'Gaus, The Presidency, 43 AM. Pol. Scr. Rev. 952, 958 (1949). 
Some of the major proposals aimed at revamping the President's staff services are presented in chronological order.

\section{Presidential Staffing Plans-I9I8-I930}

Nearly forty years ago, Henry Litchfield West wrote a book ${ }^{8}$ in which he proposed to channel congressional energies into the job of national administration, thereby relieving the President of many of his executive obligations. Mr. West's idea of bolstering the Presidency was to emasculate the President's office by making cabinet members individually responsible to both houses of Congress. In addition, cabinet members were to have seats in both the Senate and the House, but unlike Woodrow Wilson's plan for cabinet government, the President was to be retained as a figurehead. The West plan would result in departmental secretaries being responsible to three masters instead of one, and its basic premises are in complete disregard not only of the holy writ of administrative doctrine, but of common judgment as well.

In June 1920, C E. McGuire published an article in the Harvard Graduates' Magazine in which he urged that federal independent regulatory bodies be integrated with presidential policy through a central committee, which he would call the Council of Independent Establishments and which would be attached to the President's Office. This Council would share with the regular cabinet a permanent secretariat under the direction of the Secretary of the President. Implicit in McGuire's recommendations are suggestions for a presidential chief of staff, the first such suggestion on record, and a cabinet secretariat. ${ }^{\text {? }}$

Such a bureau, under the direction of one man, who would be not only Secretary to the President and Secretary of the Cabinet, but also Chairman of subordinate committees of executive and advisory officials, could not but enable the President much more effectively to keep in touch with the manifold activities and plans of the various branches of his great trust. As things are now, the President possesses great powers and must answer for even greater responsibilities, but he lacks a switchboard of intelligence, however much mechanical and clerical assistance he may have at his disposal. It is incredible how haphazard, hit or miss, and crudely uncertain is the information he and his Cabinet have before them, in their joint or separate deliberations. Government is still largely the work of men, if not old, at least of diminished physical resistance; and even when able, high officers shrink from the formidable physical effort required in following up their undoubted but rarely exercised right to exact prompt, accurate and relevant information from their permanent subordinates. The latter and the Administration would be more often in agreement if able men, with technical training, were discharging the duties of an exectuive secretariat.

On January I8, I924, Mr. McGuire appeared before the Congressional Joint Committee on the Reorganization of the Administrative Branch of the Government, at which time he asserted: "The thing which for the last six or seven years has impressed me as fundamentally necessary for the successful conduct of executive

${ }^{8}$ Henry Litchieleld West, Federal Power: Its Growth and Necessity (1918).

${ }^{-}$McGuire, A Programz of Administrative Reform at Washington, 28 Harvard Graduates' Magazine $573,580-81$ ( 1920$)$. 
business is a closer coordination around the Chief Executive, the Chief Magistrate."10 Before the Committee, he held up for observation the following diagram: ${ }^{11}$

\section{Principal Features of Proposed Executive Organization of the GovernMent of THE UNITEd STATES ${ }^{12}$}

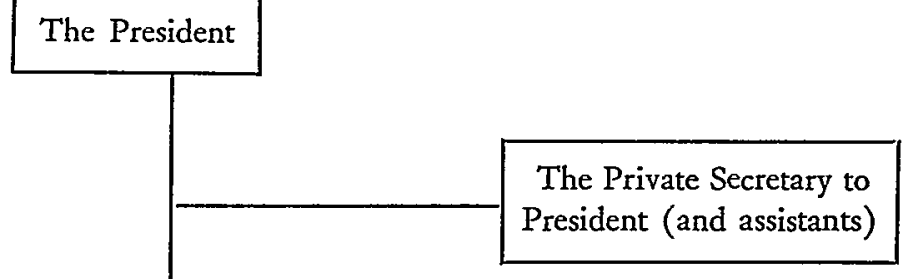

The Secretary to the President, the Cabinet, and the Council of Independent Establishments

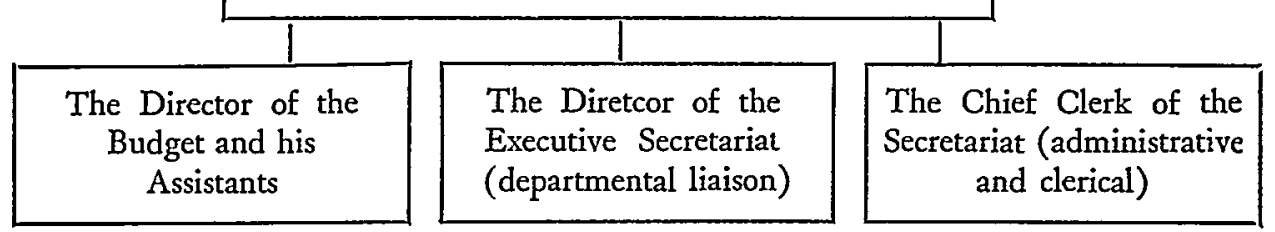

Owen Ely, in the following year, I921, conceived a similar plan for reinvigorating the Presidency at the administrative level and published his proposed reforms in the National Municipal Review. ${ }^{13}$ The Ely suggestion called for an executive secretary

${ }^{10}$ Hearings before the Joint Committee on the Reorganization of the Administrative Branch of the Government, 68th Cong., Ist Sess. 238 (1924).

${ }^{11}$ It is to be recalled that the Hoover Commission Task Force on Regulatory Commissions advocated an Office of Administrative Procedure in the Executive Office.

${ }^{13}$ An interesting colloquy transpired between Senator Reed Smoot and Mr. McGuire at the hearings: SENator SMoot: Well, let us take that idea and see how it would work out. Take your independent establishments, we will say, the Civil Service Commission, the Bureau of Efficiency ... do I understand it that you would want the representatives from those independent establishments to meet every so often and discuss the questions of their particular work at that conference and report it to the President? Mr. MCGUiRe: To meet at least at reasonable intervals; perhaps not twice a week on Tuesdays and Fridays, but to meet at reasonable intervals . . . to bring into that meeting a general statement of what they are engaged in doing, and to be prepared to take to their respective chiefs, if it were subordinates who represented the respective bodies, a statement of what the Council as a whole might have to recommend in that connection. There are a great many twilight zones between these commissions and' bodies.

SENATOR SMOOT: I was wondering what a conference should accomplish between the Interstate Commerce Commission and the Railroad Labor Board for instance? What a conference between those two establishments ... could accomplish?

The Charran: Well, there is the interdependence, of course, of rates and wages.

-....

Representative Mapes: Take the Railroad Labor Board, Mr. McGuire, and the Federal Trade Commission, or the Tariff Commission, what would they accomplish by such a conference?

Mr. MCGuire: They have, I know, a certain independence of interest, naturally. Or, I will put it this way, their representatives can contribute surely a certain amount to a conference just as the representatives of the entirely dissociated executive departments contribute now good advice to the President and to their colleagues when they come together in Cabinet meetings.

Hearings, supra note 9, at 246-47.

${ }^{13}$ Ely, The National Government as a Busizess Organization, ro Nat. MuNic. Rev. 29I, 296 (I92I). 
and for administrative offices that resembled, to a remarkable degree, the layout of the Executive Office of the President as originally conceived. The executive secretary was to head a presidential staff agency including the following functions and organizations:

(I) civil service (appointments, regulations, salaries, morale),

(2) executive appointments (investigations and recommendations to the President),

(3) efficiency and economy (standards for departmental organizations, office methods, and accounts),

(4) statistics and research (special reports to the President),

(5) public information (including library, public documents, bureau of information and complaints),

(6) public buildings and grounds, and

(7) liaison.

Like the McGuire proposals, the Ely plan attempted to consolidate independent establishment policy with presidential policy. But Mr. Ely chose the method later recommended by the President's Committee on Administrative Management and partially applied in the case of many government corporations, i.e., placing them within appropriate departmental units for executive and over-all policy purposes.

Mr. Ely went to some length to describe the functions of the executive secretary: $:^{14}$

The executive secretary is a new post, the creation of which is suggested by the vast growth of the department as a business [executive] organization. In general he would combine the posts of secretary, comptroller, and statistician in the corporate form of organization. He would also take over many of the important duties which at present devolve upon the president's private secretary.

At another point, Mr. Ely continued: $:^{15}$

Finally, we have the Executive Secretary, whose duties would be to supervise the departmental routine in general. The work of the civil service commission would be turned over to him entirely, as would also be the question of executive appointments. The present highly inefficient system of payment, promotion, and rules of service would be reformed and systematized.

The secretary would also undertake for the president various studies in efficiency and economy, for which it is now necessary to create special boards or commissions; and he would act as "aide-de-camp" to congressional committees going scandal-hunting among the departments. His department would include a bureau of public information with an office to receive suggestions and complaints from the public. At the present time the president and the cabinet members receive a large volume of complaints to which they are unable to give proper attention. With a bureau detailed to give special attention ... a great deal of waste time and routine labor can be eliminated.

W. F. Willoughby proposed the establishment of a Service of General Administration which would assist the President in his functions as general manager of the 
national government. ${ }^{16}$ Dr. Willoughby justified the creation of this new staff unit on the ground of the terrific press of business to which the President had become subject after the First World War.

If he is efficiently to perform his duties as general manager of the business corporation he must be provided with an agency, or agencies, which will do all the preliminary work of assembling and stating the facts and drafting proposals for action, to the end that the President himself will be called upon merely to formulate general policies and make important decisions, and will subsequently attend to the details of seeing that these policies and decisions are put into effect. ${ }^{17}$

Willoughby's plan called for organizing the Service into four major bureaus:

(I) the Bureau of the Budget,

(2) the Bureau of Personnel Administration (formerly the Civil Service Commission),

(3) the Bureau of Material (formerly the General Supply Committee), and

(4) the Bureau of Investigation (formerly the Bureau of Efficiency).

The Service of General Administration was to be headed by a commissioner, who would serve as business manager for the President without senatorial confirmation. It would be legally independent of other departments, and the commissioner would be aided by an assistant commissioner of the Service of General Administration.

Business procedures and techniques would be determined, under this plan, through an administrative council, composed of the commissioner, the assistant commissioner, the four bureau directors, and the president of the Civil Service Commission. Rules and regulations in the field of personnel management were to be determined by the administrative council. The Bureau of Personnel Administration would administer these rules, and a revised Civil Service Commission would be left the job of advising the President in respect to personnel matters and acting as the guardian of the merit system.

The idea of a Department of Administration has had numerous adherents since Mr. Willoughby developed the broad outlines. After the Second World War, serious recommendations for such a department were made again, and it was thought clever by some to introduce the innovation of assigning the Vice President to head this department. It was argued by opponents of the idea of a Department of Administration that any secretary assigned to the headship of the Department would incur the resentment of the other department heads and that (unless he were the Vice President) he would not be accepted as an equal. Experience with personnel and budget directors in the armed forces was cited as evidence to support this contention. It was also maintained that viewing the head of the Department as a full-fledged

${ }^{16}$ W. F. Willoughby, The Reorganization of the Administrattve Branch of the National GOVERNMENT (I923).

${ }^{17}$ Proposal for a Service of General Administration of the National Government of the United States, 7 Public Personnel Studies 167 (r929). The proposal described in this article was prepared under the leadership of the Institute for Government Research, Washington, D. C., of which William F. Willoughby was Director. 
cabinet member would tend to orient the position politically, whereas it should have a professional orientation. Another objection raised was that the position might become so powerful that it would challenge the position of the President, encouraging splits in the administration and tending to make administrative management more the business of Congress than the President. A fourth major handicap, which some opponents thought implicit in the idea, was that the agency might tend to stress the control functions of central staff units rather than service functions.

\section{The Nineteen-THIRTIES}

While the Report of the President's [Herbert Hoover] Research Committee on Social Trends did not bother much about suggesting structural details, it recognized the presidential need for a planning agency of a sort: ${ }^{18}$

Out of these methods of approach it is not impossible that there might in time emerge a National Advisory Council, including scientific, educational, governmental, economic (industrial, agricultural, and labor), points of contact, or other appropriate elements, able to contribute to the consideration of basic social problems of the nation. Such an agency might consider some fundamental questions of the social order, economic, governmental, educational, technical, cultural, always in their interrelations, and in the light of the trends and possibilities of modern science.

Another proposal for a department or bureau of administration was submitted by James Hart in a chapter entitled "The President and Federal Administration" which appeared in a symposium, Essays on the Law and Practice of Governmental Administration. ${ }^{19} \mathrm{Mr}$. Hart's proposals assume the President to be an administratorin-chief, and he insists that this fact be frankly accepted. His plan was an effort to provide appropriate administrative machinery to enable the President to discharge his managerial duties. Hart writes: ${ }^{20}$

The President should be the focal-point of the institutional supervision of all administrative services. He would then be the general manager responsible for the regulation and control of the administrative machine as a machine. For the exercise of this responsibility Congress should create as a direct agency of the President a bureau of general administration. It should vest in the President the functions of budget-making, of centralized purchasing, of allotment of quarters. ... The President, of course, would only make the crucial choices, while the bureau would attend to details. Its head should be appointed by the President. ...

S. Lyle Post, in the same year, published an article in the American Political Science Review, in which he recommended a general staff agency in the form of a department of planning and general administration. ${ }^{21}$ Uniqueness is suggested in that he would mix administrative management functions in a planning department

\footnotetext{
${ }^{18}$ President's Research Committee on Social Trends, Recent Soctal Trends in the U̦ited States xxïi (1934).

${ }^{10}$ Charles G. Haines and Marshall E. Dimock (Eds.), Essays on the Law and Practige of Governamental Administration 47 (1935).

${ }^{20} I d$. at 72-73.

21 Post, Coordination of National Administration, 29 Ax. Poz. Scr. Rev. 269 (1935).
} 
dealing also with policy formulation in substantive fields. Mr. Post describes his planning department as having three central purposes: economic welfare planning, social welfare planning, and defense planning. It is impossible not to appreciate his administrative perspicacity. And it should be remembered that he wrote four years before the Executive Office came into being and over a year before President Franklin D. Roosevelt called his famous administrative research team into being: ${ }^{22}$

Our planning department would consider only those problems which affect the relationship of one administrative unit to another. It would be a coordinating agency. Furthermore, this staff agency should have no directorial authority. It should be advisory and investigational only. Plans prepared by this agency would have no effect until approved by the President. The execution of all plans should be left to the departments and establishments. In this way, coordination on the basis of purpose can be accomplished without destroying the sense of responsibility of the line officials, such as departmental and bureau heads, for the direction and coordination of their respective units.

John M. Gaus, in 1936, also wrestled with the problem of staffing the President and announced his conclusions in an essay ${ }^{23}$ appearing in a collective work written by Professors Gaus, Leonard D. White, and Marshall E. Dimock. The core of Professor Gaus's remedies consisted of adding six top-flight administrators to the President's staff, one of whom would serve as a general secretary to the cabinet "to coordinate material coming to it for decisions, to transmit the decisions reached to the departments and to follow up on the action taken to check performance." In addition, Gaus's plan provided that each of the other five general administrative staff assistants would be charged with the coordination of activities around a nucleus of related major functions. The five fields in which the presidential assistants or functional coordinators would work were to be: physical resources planning; transportation; defense; money, credit, and finance; and social welfare.

In point of time and in likeness of implication, William Y. Elliott's technical study for the President's Committee on Administrative Management ${ }^{24}$ resembles the Gaus study. Professor Elliott recognized the deep-seated need of increased aid for the President to help him make more reliable decisions affecting public policy. In short, he proposed that a secretariat be established immediately beneath the President with the primary duties of augmenting the effectiveness of the cabinet by serving as its coordinator and of furnishing the President with authentic data as to over-all policy developments in government.

Elliott postulated that if the nature of cabinet proceedings could be improved by the secretariat, the cabinet could be transformed into a more important unit, but he warned: "If cabinet members continue to be chosen for the combination of political 'availability' and fair grade administrative talent-the President must turn

${ }^{22}$ Id. at 274 .

${ }^{23}$ Gaus, $A$ Theory of Organization in Public Administration, in The Frontrers of Public AdminISTRATION 66 (1936).

24 William Y. Elliot, The President's Role in Administrative Management (unpublished document in the Library of the Graduate School of Public Administration, Harvard University, 1936). 
elsewhere for that direct discussion and informal presentation of administrative policy which he so much needs." ${ }^{25} \mathrm{He}$ rejected the idea of erecting the secretariat into a supercabinet, for he feared that superior rank might even be a positive disadvantage in dealing with cabinet members jealous of their own high place. It was urged that the cabinet secretariat report daily to the President and the cabinet members on "groups of activities rather than on departmental details." To assume responsibility within those broad policy areas, Elliott proposed subdividing the secretariat into five main sections:

(I) A Fiscal Board, which would serve to integrate the fiscal policies of the Bureau of the Budget, the Treasury, the Securities and Exchange Commission, the Reconstruction Finance Corporation, the Federal Reserve Banks, and other agencies engaged in lending and those immediately concerned with the over-all tax policy of the government.

(2) A Permanent Defense Board, which would deal with the fighting forces in the manner of the British Cabinet Secretariat's relationship to the Committee of Imperial Defense.

(3) A Social-Security Board, which would be alert to policy disclosures respecting education, public health, and employment.

(4) A Business Conditions Board, which would oversee two main types of business policy. One division of this section would be interested primarily in commercial policy proper, e.g., tariff, commerce, agriculture, etc.; the other would be attentive to regulatory policy affecting public utilities and other regulated interests. On the subject of integrating regulatory policy into the wider commercial policies, he took an unequivocal stand: "It is essential that the independent regulatory commissions should report to the President through the Cabinet Secretariat if governmental policies are to be coordinated. ... Cooperation of these commissions in the work of the administration can take the form already illustrated by the Tariff Commission's valuable cooperation with the Trade Agreements Section of the State Department."28

(5) A National Planning Committee which should be installed in the cabinet secretariat to plan and to entertain ideas relevant to long-run considerations. According to the Elliott plan, paralleling these groups would be advisory councils whose job it would be to keep the secretariat in touch with informed sources, other than the executive agencies. The presidential assistants would serve as secretaries to these councils and their chairmen would be selected from the best qualified congressional committee chairmen and cabinet members.

Under this plan, top personnel would be political appointees. But the Director of the Budget would be ex officio the executive secretary of the secretariat. Elliott explained that appointing the Director of the Budget as head of the secretariat would conform to the British practice of choosing the Permanent Undersecretary of the

${ }^{25} I d$. at 6.

${ }^{20}$ Id. at 7 . It is to be recalled that today the Council of Economic Advisers analyzes regulatory policy in terms of its effect upon the Government's program. 
Treasury to head the Cabinet Office. The permanent personnel, it was suggested, could be selected for a limited tour of duty from agencies already in existence. This scheme would have certain obvious advantages, for men secured in this way would be experienced in duties of line administration and "conscious of their ultimate return." This detail was not proposed without reservation, for it was recognized that men trained in one department of the Government would necessarily bring with them the usual bureaucratic trait, sometimes described as departmental loyalty, which might tend to make them excessively aware of the effect which certain policies might have on their former agency and future job. By having the personnel to agree, on accepting the current job, not to return to their old agency, the secretariat might utilize their experience without fear of jeopardizing policy considerations.

A secretariat of this type would make available to the President and to the cabinet a reporting service devoted to developing "not only summaries of actual performances, but indications of lines of policy, probable effects and difficulties as experienced in operation." Also, independent research performed by the secretariat would provide the executive with means of keeping tab on individual departments and the reliability of their reporting methods. Equally important would be the "intelligence" function of the secretariat, which would augment present systems of informing the President of the estimates of legislative attitudes and the political feasibility of policies under consideration.

This proposal, in slightly revised form, was the subject of a memorandum that Professor Elliott addressed to Mr. Matthew J. Connelly, Secretary to President Truman, on November 27, 1945 . One of the points established in this communique to Mr. Connelly was that the weekly meetings between the President and congressional leaders were inadequate as a means of bridging the gorge between the legislative and executive branches, and that the "thing missing is preparatory work in the formulative stages of policy, which should be going on from day to day and before the lines are hardened and prestige issues are raised."2 ${ }^{2 \pi}$ To illustrate his point, Professor Elliott commented upon the existence of an efficient joint staff working with the House and Senate taxing committees, which had been able to coordinate revenue proposals very well within the Congress. But this close tie did not prevent the development of wide divergencies between the Treasury's positions on tax bills and that of the House and Senate. An advisory council, attached to the Executive Office, upon which members of Congress and their staffs as well as executive fiscal officials could serve, would enable the legislator and the bureaucrat to seek out common ground well in advance of action on the Hill. Rather than having an official designated as executive secretary heading up a cabinet secretariat, as in 1936, Elliott would have a chief of staff in the office of the President, who would be somewhat comparable to the Director of War Mobilization and Reconversion and to his own original conception of a staff chief, the executive secretary. The presi-

${ }^{27}$ Memorandum from William Y. Elliott to Matthew J. Connelly, Nov. 27, 1945, p. 2. 
dential chief of staff would superintend policy as well as administrative management problems through seven distinct functional groupings:

(I) fiscal policy,

(2) defense and foreign policy,

(3) public welfare,

(4) physical planning,

(5) commercial policy (and two additions over 1936),

(6) organizational and personnel policy, and

(7) the constitutional and legal framework.

In his conclusions, Elliott flirted with the idea of a supercabinet, but realistically abandoned the idea as impractical in the context of American history. ${ }^{28}$

If it were possible to begin over again or to make a clean sweep of politics and sectional considerations deeply imbedded in our political system, it might be the right thing to set up a sort of super-cabinet under an assistant President modeled on the lines of a military general staff. But to cut so deeply into political habits and traditions is probably outside the range of practical politics at this time.

\section{The President's Commitree on Administrative Management}

The plan for augmenting presidential staff facilities as developed by the President's Committee on Administrative Management has been of historic importance and, although now somewhat dated, continues to exercise a heavy influence upon professional thinking about presidential staff concepts.

The immediate progenitors of the Executive Office of the President were unmistakably Messrs. Louis Brownlow, Charles E. Merriam, and Luther Gulick. They voiced the simple phrase, "The President needs help," and then proceeded to devise means for supplying that help. They recommended the reduction of the number of reporting agencies to twelve to accommodate the President's "span of control" and drafted a blueprint for an administrative staff agency, which they labeled the Executive Office. The Office, as eventually established two years following the submission of the Report to the President, was patterned almost exactly along the lines advocated by the Committee. ${ }^{29}$

Whereas the Brownlow plan called for more White House secretaries, a larger contingent fund for hiring aides on a temporary or project basis, six administrative assistants, and the grouping of the Bureau of the Budget, a Civil Service Administrator, and National Resources Board together into one staff agency, the actual

${ }^{28}$ Elliott, supra note 27 , at 4 .

${ }^{20}$ Herman Somers' thesis, Coordinating the Federal Exectitive, is in disagrecment, for on page $3 \mathbf{I}$ the following sentence appears: "The recommendation for the Executive Office of the President is not to be found in the Report of the Committee." Actually, the Report does refer to an Exccutive Officc. "The three managerial agencies, the Civil Service Administration, the Bureau of the Budget, and the National Resources Board should be a part and parcel of the Executive Office. Thus the President would have reporting to him directly the three managerial institutions whose work and activities would affect all of the administrative departments." President's CommitteE on Administrative Mansoement, Administrative Mansgement in the Government of the United States 6 (1937). 
reorganization of 1939 satisfied most of the Brownlow points, but the Civil Service Commission was maintained intact. In place of the proposed Civil Service Administrator, President Roosevelt established the Liaison Office for Personnel Management, and he employed one of the Administrative Assistants to fill that position. ${ }^{30}$

British administrative thinking left an indelible imprint on the members of the President's Committee. The Ig18 Haldane Report on the Machinery of Government fixed the principle of departmentalization for the Committee, and the British Treasury, with its financial side and its Establishment Branch, may have been a basic denominator in assisting the members to reach agreement on the nature of presidential staff needs. ${ }^{31}$

It is rather interesting to note that although seven of nine major executive reorganization studies ${ }^{32}$ appearing prior to 1937 and entertaining ideas of reforming the Presidency included the addition of a central administrative official, who would be the principal assistant to the President, the President's Committee saw fit not to make such a proposal. Not only did the Committee's decision against a so-called presidential chief of staff run counter to public administration thinking before I937, but also against much theorizing after the publication of the Report.

\section{The Griffith Pian}

Two years after the President's Committee on Administrative Management made its report, Ernest S. Griffith, formerly of Harvard University and currently Chief of the Legislative Reference Service of the Library of Congress, in a brilliant work, The Impasse of Democracy, came to grips with this challenging problem of providing the President an administrative mechanism for over-all policy review and coordination. He devised a rather unique scheme that called for setting up a central planning agency, to be advisory to both the President and the Congress. Working beneath, but not legally responsible to the central planning agency, were to be a network of functional authorities. The central planning agency would merely make suggestions to and advise these autonomous functional groupings; it would not control them. The central planning agency would be of the board or commission type and it was to be composed not of representatives from specialinterest groups, but of men with broad points of view and exceptional intelligence. The board was to consist of four economists, one sociologist, one expert in public spinion, and one public administrator, a total membership of seven. It would be provided with its own research staff for the purpose of making independent legislative proposals or for direct intervention in executive affairs.

\footnotetext{
${ }^{30}$ Legal authority for the establishment of the Executive Office of the President is to be found in the following: Reorganization Plan No. I, transmitted April 25, 1939; effective July I, I939; Reorganization Plan No. II, transmitted May 9, I939; effective July I, I939. Joint Resolution of June 7, I939 (S. J. Res. 138) set the effective date of Reorganization Plans I and II-notwithstanding provisions of the Reorganization Act of 1939-for July I, 1939. 53 STAT. 813, 5 U. S. C. 133S (1946). See 84 Cong. REC. 6735, 6739, 7201 (1939).

${ }^{31}$ See Sir Henry Bunbury, The Problem of Government in the United States, 17 PuB. Aomis. 10 (1939). The idea of a planning agency in the Executive Office struck Bunbury as a "novelty."

${ }^{32}$ See Edward H. Hobes, Executive Reorganization in the National Government (i952).
} 
Members of the agency would be appointed by the President, by and with the advice and consent of the Senate, for overlapping long terms. They would be nominated from panels of eligibles prepared by the Civil Service Commission. In order that a steady liaison service could be maintained between the functional authorities and the central planning agency, it was suggested that the agency be represented on each of the authorities. The task of these authorities would be to investigate exhaustively and to recommend policies pertaining to major industrial, agricultural, commercial, and professional activities of the country. Representation on the authorities would be given to the major interests involved. For example, the steel industry authority would have the following representation: "'Control Group'' 3 members; employees or United Steel Workers of America, 3; Independent Iron Mine Owners, I; Railroads, I; Automobile Industry, I; Construction Industry, I; Social Security Board (to represent unemployed), I; Federal Trade Commission (to represent 'consumers of consumers'), I; the proposed Central Planning Agency, a liaison man for over-all planning, I." ${ }^{33} \mathrm{Mr}$. Griffith spelled out his plan in intricate detail: $:^{34}$

For advisory purposes the Central Planning Agency might organize itself into at least five bureaus, corresponding in general to the areas of national economy which have emerged in our discussion as needing administration. One of these could assume general oversight over the land, mineral, waters, fisheries, forest, and other natural resources of the nation; scrutinizing proposals and subordinate legislation from departments such as Agriculture and Interior and agencies such as the Federal Power Commission.... This would correspond to that planning for future generations which was the peculiar contribution of an emphasis upon the interrelations of resources. Another could assume general oversight over legislative proposals dealing with 'social dividends,' including wages, hours, and social security, and subordinate legislation emanating from the Department of Labor, the Federal Security Administration, etc. A third bureau could deal with fiscal policy, scrutinizing Treasury proposals from the standpoint of their secondary effects on economic and social adjustments and relationship. This bureau or a second closely related bureau might also assume the contemplated measure of control over the national money and credit policy. A fourth bureau should be responsible for surveying the activities and legislative proposals of the various regulatory commissions and authorities dealing with industry, commerce, and foreign trade, and also situations in the unregulated segments of the national economy which seem to call for adjustment. It would have a division of adjustment to serve quasijudicially in disputes between or concerning authorities. There should also be a fifth bureau of statistical research, which would utilize and interpret the findings of the existing research bureau in the Federal Reserve Board, the Treasury, the Departments of Commerce, Labor, and Agriculture, and other public and private agencies. It would advise the Agency on the state of the nation and suggest measures. Each bureau might exercise a suspensory veto over quasi-legislative orders emanating from other government departments and commissions, which affect interests other than those presumably represented in the respective clienteles, or which involve over-all adjustments.

Mr. Griffith suggested the possibility of converting the then existing National Resources Planning Board into this central planning agency. The most striking char-

${ }^{33}$ Ernest S. Griffith, The Ixipasse of Democracy 319 (1939).

s4 Id. at $327-28$. 
acteristic of this plan is its basic similarity, of course, with certain variations, to the earlier plans of Gaus and Elliott, i.e., the idea of controlled functional groupings dominating each major area of policy, with a central coordinating point short of the President himself.

\section{Staffing Plans and the Forties}

The mid-forties saw two serious students of public administration, Arthur MacMahon, of Columbia University, and V. O. Key, formerly of Johns Hopkins and Yale and presently of Harvard, match their managerial skills with the problem of producing an organ of synthesis and control for the President of the United States. ${ }^{35}$ Professor MacMahon envisaged "a new type of department overseer, assigned to a broad domain of policy, equipped with a compact staff, and exercising his influence partly as high adviser and partly as negotiator, and also as the source of coordinating suggestions, directives, and decisions."36 A cabinet secretariat would pull the loose ends together, and the cabinet itself would become both larger and smaller, being in effect what MacMahon chose to call a "double body." An inner cabinet of the chief policy formulators would serve as keystones in the presidential arch, but the cabinet "as a whole might be expanded to embrace the heads of all the great operating departments. The number of these might increase to a score, for few believe that departments of this sort can be held to the dozen recommended in 1937."37 This latter suggestion for an inner circle within a larger concentric body reflects a degree of British influence and is somewhat reminiscent of the days of Roosevelt's National Emergency Council. Professor Key's study stresses the need for a cabinet secretariat as a central policy coordinating nucleus and conjectures about the reasons why the Bureau of the Budget alone could never become such a nucleus.

Don K. Price, Rhodes Scholar and formerly with the Washington Office of Public Administration Clearing House, enunciated the provisions of a presidential staffing plan in I946. Mr. Price wanted to see a new staff unit created that would deal directly with line operators, but still have no direct authority over the department and agency heads. Upon authorization from the President, it could call appropriate executive officials together and try to work out a common approach. In the event of unresolved differences, a minority and majority report would be channeled through this unit to the President for his final resolution. Price believed that such meetings should be held in the White House and the President should nominally be the chairman, but after the first meeting of the group, the chief of the secretariat would preside. But the President would at all times have the privilege of joining the group whenever he might believe it necessary. It was suggested that the President could enforce attendance at these secretariat meetings if he were to refuse to discuss high policy matters individually with the department heads

${ }^{35}$ MacMahon, The Future Organizational Pattern of the Executive Branch, 38 AM. Pot. Sct. REv. 1179 (1944); Key, The Reconversion Phase of Demobilization, id. at II37.

${ }_{30}$ MacMahon, supra note 35 , at 1186.

${ }^{a 7} I d$. at 1187 . 
and if he would cooperate with them only after information and issues had been systematically cleared through the secretariat.

Mr. Price imagined that perhaps some of these agency groups might become continuing committees, or presidential policy committees. But he warned: ${ }^{38}$

... the President, however, should have it clearly understood that any such "committee" was not to acquire a fixed frame of reference, a fixed membership, and a separate secretariat-in other words, an independent corporate status of its own. A formal status would destroy the group's usefulness to the President, who would need to manage its relationship with other similar groups with great elasticity. He would gain nothing if he set up committees to bridge the differences between his departments, only to have a set of jurisdictional conflicts between the committees themselves to deal with.

Subordinate committees working around the perimeter of these basic policy committees might serve useful staffing purposes and bring lower echelon officials into the policy-formulation picture. Mr. Price also warned that the secretariat should not make decisions of its own and that the President should never come to rely on the advice of a single official. He discouraged the concept of a chief of staff, or an Assistant President, on the grounds that such an official might develop political ambitions, and even though he did not, Congress and the opposition party members would try to play the two off against each other. "If the President puts his policies at the disposal of one man, he will virtually lose the right to discharge him. $\mathrm{He}$ could not fire an alter ego without in effect, giving himself a vote of no confidence. The surest way for the President to become a mere Constitutional monarch would be to make someone else his prime minister." In addition, he argued that the components of the Executive Office should not be frozen by statutes and that the President should be allowed to pick his immediate aides without senate confirmation.

Much of Mr. Price was written into part II, "The Executive Office of the President" of the first Hoover Commission report, General Management of the Executive Branch. Mr. Price's influence on Mr. Hoover, as his close adviser, is evident in this report, but Mr. Price is the last person to claim this influence. He has insisted that that report was the ex-President's, strictly his. But when the Hoover staff plan is lined up, point by point, with Price's staff concepts, the similarity is much more obvious than are the differences. They both recognize the need for a presidential secretariat, and they both express unstinting fear of a chief of staff to the President and of congressionally imposed rigidities in the Executive Office.

Herman Somers, of Haverford College in a sense belongs with the Gaus-Elliott school of thought, which is less concerned over the dangers inherent in a chief of staff and believes that more is to be gained from an orderly funneling of policy through definite functional limits than lost from any additional jurisdictional squabbles which conceivably might ensue among these policy clusters. Professor Somers blueprinted his staff organization in 1947 in a doctor's dissertation on the

${ }^{38}$ Price, Staffing the Presidency, 40 AM. PoL. Scr. Rev. II54, I166 (1946). 
Office of War Mobilization and Reconversion. ${ }^{39}$ In this study, he offered sweeping recommendations for large-scale reorganizations in the Executive Office, calling for a chief of presidential staff to head an Office of Program Coordination and Cabinet Secretariat. Fanning out beneath this Office would be an elaborate coordinating staff, organized into cabinet committees and serviced by a secretariat. There would be a National Defense Resources Office, a Planning Office, an Office of Budget and Management, each supervised by a Director. The White House would be streamlined, and two subdivisions would be clearly indicated, an Office of Congressional Liaison and an Office of Press Secretary. As an internal coordinating device for the presidential staff units, there would be created an Executive Office Committee, chairmanned by the President, and in his absence, by a chief of presidential staff, who would also be a member, along with the Director of the Budget and Management, the Director of Planning, the Director of Congressional Liaison, and the Press Secretary. ${ }^{40}$ All lines of responsibility and authority lead directly to the President, unobstructed by clearance points, but the National Defense Resources Office, the Planning Office, and the Office of Budget and Management are to serve as back-staff to the chief of presidential staff. The main functions of the Executive Office should be to: $:^{11}$

"(a) Delineate spheres of policy responsibility and reconcile policy conflicts among agencies when jurisdictional questions arise.

(b) Follow through to review policy activities of agencies in conformance with over-all policy.

(c) Help coordinate and unify the work of individual agencies severally involved in particular policies.

(d) Enforce continuous cross-reference among agencies involved in related activities.

(e) Create additional interagency action committees where effectuation of policy appears to require it. Such Committees may frequently be comprised of the "Assistant Secretary' level of agency representative.

(f) Serve as liaison with the Office of Budget and Management where administrative or organizational arrangements appear inconsistent with policy objectives."

These recommendations were offered by Somers after he had held an important position in the Office of War Mobilization and Reconversion, and they are deeply rooted in his wartime experience at the White House.

Somers has not waged his battle for a peacetime equivalent of the Office of War Moblization and Reconversion alone, for numerous highly regarded academicians, the members of the Colmer Committee, ${ }^{42}$ three major OWMR deputies, and others

\footnotetext{
${ }^{30}$ Herman Somers, Coordinating the Federal Executive (1947). See also his book, Presidential Agency (1950), in which he refines this thesis.

"See Herman Somers, Coordinating the Federal Executive 540 (I947).

11 . at $546-47$.

19 Its final report states: "The committee recommends the continuation of a Presidential agency to act as a sort of over-all general staff to coordinate the formulation and execution of policy." See House Special Committee on Postwar Economic Policy and Planning, Reconversion Experience and Current Economic Problems, H. R. REP. No. 2729, 79th Cong., 2d Sess. 5 (1946).
} 
have sought to reform the Executive Office structure around an OWMR model. Richard Neustadt attacks this proposal, however, with uninhibited directness: ${ }^{43}$

Proposals of this kind tend to overdramatize the importance of organization charts and give the appearance of calling for major additions of new staff. The O.W.M.R. deputies used sometimes to talk about twenty-five top-level staff members for their pro. jected program office. This appears to be something of a contradiction in terms, and seems unduly large, considering the available facilities of other staff units. But taking it on its face, there are unquestionably already that many people, and more, equipped to do that kind of job in the present Executive Office.

George A. Graham is similarly critical of a peacetime structure resembling that of the OWMR: $:^{44}$

The Office of War Mobilization, it may be conceded, had limited success, perhaps based on the then current philosophy that one should put up with anything if it would help win the war; but its life could not have been long. In order to preserve O. W. M. R., or a species of that sort, it would have been necessary to reconstruct the environment completely, that is to revolutionize the Presidency and drastically alter the departmental system.

An interesting although unique proposal in 1948 was formulated by G. Homer Durham in the pages of the Public Administration Review. After an analysis of the administrative structure of the Mormon Church, Professor Durham concluded that its highly centralized pattern of controls is applicable to the Executive Office of the President. He would include within the Office a presidential council through which a formalization of the services rendered by the Amos Kendalls, Colonel Houses, Harry Hopkinses, John Snyders, and Clark Cliffords could be achieved. The council, with a suggested membership of twelve, would provide the President with a pool of special representatives freed from administrative routine. Their salaries would run from cabinet rank to Supreme Court Justices. These representatives, serving at the pleasure of the President, would be empowered to represent him in holding conferences, in cooperating with interdepartmental committees, or in performing such duties as indicated by the President. Durham declared that ". . . it may be stated with reason and not tongue-in-cheek that if the Kingdom of God requires apostolic messengers and delegates American government would be following good and lofty precedent." ${ }^{35}$ Durham's novel approach is projected into his conclusions, as above, and also through his assumption that minority partisans should be included in the presidential council. He pointed out that Democratic

\footnotetext{
${ }^{13}$ Richard E. Neustadt, Presidential Clearance of Legislation (unpublished doctoral dissertation in Harvard Law School Library 1950). For an account that deplores the continuing development of presidential staff units on the basis that it destroys centralized responsibility, see Hogan, $A$ Dangerous Tendency in Government, 6 PuB. ADMn. REv. 235, 239 (1946), and an answer by Bequist, Coordinating Staff-Are They Really Dangerous?, 7 PuB. Admin. Rev. 179 (1947).

"See "The Presidency and the Executive Office of the President," a paper given before the American Political Science Association, Section 51, Dec. 30, 1949, but not published in the Revietw.

${ }^{4}$ Durham, Coordination by Special Representatives of the Chief Execritive, 8 Pud. Admin. Rev. I76, I 80 (1948).
} 
Presidents had used Herbert Hoover and Wendell Willkie on "apostolic" messenger assignments.

A somewhat similar plan was advanced by Joseph Rosenfarb in 1948. ${ }^{46}$ The cabinet was to be extricated from its duty of administering the departments, and each member was to serve without portfolio in a kind of council of ephors. The secretaries would be supplanted by an elite class of technically trained public administrators, who would come to their jobs with the requisite skills. As a corollary to this recommendation, a Department of Government would be created to "keep constant supervision over the process of administration and advise the President and his cabinet on reorganizational projects and administrative techniques."47 $\mathrm{He}$ also advocated a planning system that would correspond to the wartime bureaucracy: a Public Requirements Board would ascertain total needs, a Resources Industry Board would keep an inventory of our resources and plan their use and conservation, a Production Planning Board and the equivalents of the Office of Price Administration and the National War Labor Board would integrate the wage-price relationships. Coordinating and developing the President's program would be the job of the newlyemancipated cabinet members and the President himself. Apparently, these recommendations were made with little or no investigation of the Office as it was currently constituted, and it failed to explain how the President should go about utilizing his cabinet officials now torn away from their administrative moorings and elevated to the limbo of elder statesmen, likewise a defect of the Durham proposal.

The year 1949 was one of the richest in terms of producing a variety of literature on the subject of renovating presidential government. One of the most far-reaching of these proposals was prepared by Arthur C. Millspaugh in his Toward Efficient Democracy. Millspaugh proposed scrapping the President and the House of Representatives and bringing forth a new constitution having three principal political organs:

(I) a national council of twenty-one members possessing all national legislative and executives powers,

(2) a senate, as presently constituted, with only suspensive powers of review, and

(3) a chief executive appointed by and responsible to the national council. "This supreme conciliar organ, which would do its work through a series of committees, would be frankly rigged in behalf of the two party system." ${ }^{\text {88 }}$ This system would mean the abandonment of the advantages of a government of separation of powers, but it would also cancel out some of the disadvantages. The problem of the President is solved simply by doing away with him and substituting an executive responsible to a pluralized policy council for centralized leadership. Apparently, this is an effort to draw upon the experience of state administration, where various boards, health and welfare, for example, select a manager to administer programs

\footnotetext{
${ }^{\circ 6}$ Joseph Rosenfarb, Freedodr and the Administrative State (1948).

${ }^{47}$ RosenFarb, op. cit. supra note 46 , at 229.

18 Arthur C. Millspaugh, Toward Efficient Democracy c. 6 (I949).
} 
within the limits of policy as established by the board. Under the present Constitution, the Millspaugh plan offers nothing of value by way of streamlining the President's staff services. His politico-administrative arrangement represents a compromise between the single and plural executive, but unless party lines were to become more rigid than they are now, national administration might be even more frustrated than under the present Constitution.

C. Perry Patterson went all out for a plural executive in an article "The President as Chief Administrator," which appeared in a I949 issue of The Journal of Politics. His argument is as old as Woodrow Wilson's brief for cabinet government and closely akin to Herman Finer's. It is simply the idea that several heads are better than one, even in presidential administration: ${ }^{49}$

The weakness in the President's control of administration is not lack of authority, but the impossibility of one man's handling the job. Time, physical strength, and the mammoth character of the task would veto the efforts of even a superman if he had nothing else to do and even if the administrative machine was better organized to facilitate his control. ... We have discovered that a single executive has its weakness as well as its elements of strength. A plural executive with each member having complete authority over a single department is incomparably superior to a single executive for administrative purposes.

This position overlooks the difficulty of coordinating a program or programs around a plurality, a feat which is even more strenuous than coordinating programs around a single, final executive authority. Many proponents of cabinet government are inclined to overlook the fact that Great Britain herself has not licked this problem of achieving coordination through so-called responsible government. In fact, there are Englishmen who contend that the plural executive serves to make this utterly impossible..$^{50}$

Another work published in I949 by one of America's foremost authorities on the Executive Office is notable for its simplicity of suggestion and general satisfaction with the President's staff facilities as they were then functioning. Mr. Louis Brownlow believes that if two things (one requiring an amendment to the Constitution; the other only an act of Congress) were done, the American President would be equipped for the job he is assigned to do. Brownlow would give the item-veto power and administrative reorganization authority to the President on a continuing basis. These two things along with a cabinet secretariat, "American-Style," would, claims Mr. Brownlow, empower the President to cope with his problems on a footing of maximum efficiency. Brownlow thus disagrees with Patterson, who contends the President already has ample powers, and his reassurances as to the toughness of the

${ }^{10}$ Patterson, The President as Chief Administrator, II J. Politres 218, 231 (1949).

${ }^{50}$ L. S. Amery, Thoughts on the Constitumon (1947) criticizes the British Cabinct (even with its Secretariat) for not coordinating departmental policies. Mr. Amery, himself a member of several Cabinets and with over fifty years' experience with parliamentary government, wrote: "The result is that there is very little cabinet policy, as such, on any subject. No one has time to discuss it, to coordinate its various elements or to see its prompt and consistent enforcement. There are only departmental policies." Id. at 86 . 
Presidency must be of comfort to those who are concerned with the lasting viability of our executive institutions. ${ }^{51}$

\section{The First Hoover Commission}

The First Commission on Organization of the Executive Branch of the Government issued its first report in February of $1949,{ }^{52}$ and in it appeared a set of recommendations pertaining to the Executive Office, which, incidentally, the Commission chose to call the President's Office. Despite a lengthy inquiry into the Executive Office during President Truman's term, for reasons best known to its members, the Second Hoover Commission did not make an intensive study of EXOP under the administration of President Eisenhower. The First Hoover Commission recommended that four new additions be made to the Office: An Office of Personnel, a staff secretary in the White House Office, the National Security Council, and the National Security Resources Board. ${ }^{53}$ The Commission called for the housing of the Chairman of the Civil Service Commission within the Executive Office as director of the new Office of Personnel. And the Chairman would also be considered the principal staff adviser to the President on personnel matters as well as primus inter pares in the Civil Service Commission. ${ }^{54}$ The new staff secretary would keep an up-to-date summary of the principal issues confronting the President, and he would review the status of staff work within the Executive Office of the President. The Commission insisted that he should not be an adviser to the President on policy matters of any sort and, therefore, he should not review the substance of recommendations made by other staff officials. It was proposed that the staff secretary be a career man, like the White House executive clerk, and that he keep an inventory of cabinet and interdepartmental committees. "He should inform the President of any difficulties which have arisen because of the overlapping of assignments or conflicts of policy." Exactly how the staff secretary is to inform the President of conflicts of policy without himself dealing in policy was not made clear.

In addition, the following recommendations appeared:

Recommendation No. 2 Statutory authority over the operating departments should not be vested in any staff members or staff agency of the President's Office. ${ }^{55}$

Recommendation No. 3 The President should not be prevented by statute from reorganizing the President's Office and from transferring functions and personnel from one part of it to another. 58

${ }^{61}$ Louis Brownlow, The President and the Presidency (I949).

2 Commision on Organization of the Executive Branch of the Government, General ManAGEMENT OF THE EXecutive Branch (I949).

${ }^{53}$ Id. at 14 , 19 . Both the National Security Council and the National Security Resources Board were created by the National Security Act of 1947, 6r STAT. 495, but it was not until I949, by virtue of 63 STAT. 578, that they became an official component of the Executive Office.

E Reorganization Plan No. 5 of 1949,3 C. F. R. I38 (Supp. 1949), converts the Chairman into the Chief Administrative Officer of the Commission, but does not place him within the Executive Office.

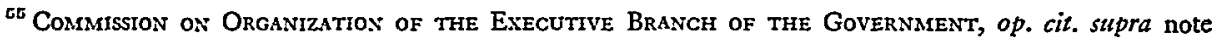
52 , at 15 .

${ }^{\text {co Ibid. }}$ 
On February I4, I949, Senator McClellan, of Arkansas, introduced S. 942, which was a variation of the Hoover Commission recommendations for EXOP, but the measure itself was violative of Recommendation No. 3 , because the bill would have infused statutory inflexibility into the office, whereas the Commission consistently argued that the President ought to be allowed to organize his staft equipment to suit his own needs and predilections.

Recommendation No. 4 The head of each staff agency in the President's Office should be appointed by the President without confirmation by the Senate except the Civil Service Commission. ${ }^{57}$

The Director of the Bureau of the Budget and the Executive Secretary of the National Security Council exemplify the principle involved in Recommendation No. 4 .

Recommendation No. 5 The Commission recommends that the Council of Economic Advisers be replaced by an Office of the Economic Adviser and that it have a single head. ${ }^{58}$

The arguments in support of this latter idea are that a plural staff body composed of members of equal dignity lends itself to internal disagreements and makes cooperation with related staff agencies more difficult. These assertions are at best debatable.

Recommendation No. 6 The membership and assignment of any Cabinet committee set up to advise the President on important policy issues should be determined by the President. ${ }^{59}$

This recommendation would have the effect of erasing the congressionally-fixed membership of the National Security Council.

In addition, the Executive Office nomenclature was to be standardized: The White House Office, Office of the Economic Adviser, the Office of Personnel, the Office of the Budget-but lo, two pariahs-a National Security Council and a National Security Resources Board. ${ }^{00}$ Why this recommendation for partial uniformity, when the old names already carried meaningful connotations?

\section{GrahaM AND Finer}

George A. Graham has suggested that a staff chief, distinguishable from a chief of staff, be placed above the Executive Office beneath the President to give it continuous, centralized direction, and that the President should appoint several supercabinet officials, who would operate in line channels as top-flight planning and action officials. They would be superior to department heads, and they would be responsible to them directly in clearing both operations and policy proposals. Thus, a new

\footnotetext{
"5 Id. at I6. $\quad{ }^{58} I d$. at I7. 17.
}

oo Supplemented by the Office of Defense Mobilization by virtue of Exec. Order No. ror93, issucd on Dec. $16,1950,3$ C. F. R. 156 (Supp. 1950 ), and later the agency was given statutory status in Reorganization Plan No. 3 of 1953,63 STAT. 203, 5 U. S. C. $\$ 1332$ (Supp. 1952), Exec. Order No. I046I, 3 C. F. R. 134 (Supp. 1953). 
layer in the Washington hierarchy would be constituted, and finally the job that Graham said needs to be done would be faced. This proposal, in some respects, sounds interesting, but there is strong doubt that the cabinet of today would be content to be subordinated to a super-body between it and the President.

Mr. Herman Finer, perhaps the most able and devout sponsor of the cabinet form of government for the United States, openly attacked the major premise of the Hoover Commission recommendations on EXOP in several classic paragraphs in a I949 issue of the Political Science Quarterly. To paraphrase Professor Finer's cogent style would be to do him an injustice. ${ }^{61}$

The problem of the presidency is not alone one of time and energy (and the terrible physical burden is more than once referred to); it is moral. The fundamental question is whether one man vested with the sole responsibility, where other men are merely his "alter ego," can bear the burden of moral choice involved in his preference of one set of values and priorities in the making of decisions. It is no use at this date quoting, as the Commission does, from Hamilton's discussion of the unity, vigor and responsibility of the executive as it appears in The Federalist, unless it is acknowledged that if Hamilton were here today he could not accept the conclusions of the Report on the basis that "the broad pattern" is sound; for it is no longer sound. One man cannot integrate; because one man is too few to take the moral responsibility. To give an answer to a political question, when the facts and advice have been presented, is not necessarily a "responsible answer"; it may be an evasion or subterfuge. "Off the cuff" has become the heart of presidential compulsion. Yes or No may be a parting from the problem, not its sober and well-weighed solution. Responsibility begins in the conscience: one man has not enough of this to meet the problems of integration-which means choice of values-for all the wide sphere of the American domestic and international empires.

Is it not clear that the desiderata cannot be met by the present constitution of the executive power of the United States? The more the Commission insists on its panacea, namely, the provision of "staff aids" to the President, the more it admits, without recognizing it, the incompetence of the presidency for more than an "off the cuff," Yes or No or Maybe. One man can hardly do anything other than stand above the battle. To the departmental chiefs the President is an excrescence; to the President the departmental chiefs are an annoyance. The President is to the departmental chiefs an excrescence because he does not mingle with them even in the top elements of their decisions; to him they are an annoyance because if they bring facts and advice to him he is bothered to know what to do about them, while if they do not he is committed by them in his reputation if he is an ordinary man, and in his conscience if he be an extraordinary one.

A full cabinet system with collective responsibility is the crying need of America- of the nation, of the Congress, of the departments, of the civil service, and of the presidency. Only if the responsibility is truly shared among fffteen or twenty men, only if the will to govern is put into commission, will it be possible to integrate the government of the United States, and secure simultaneously that all departments shall be heard, that all departments shall take notice, that all personnel shall respect their chief, that facts and

\footnotetext{
${ }^{01}$ Finer, The Hoover Commission Reports, 64 Por. Scr. Q. 405, 415, 416, 417 (1949).
} 
advice shall not run about free, equal, and wild. Nothing that the Commission proposes -the increase of the White House staff agencies, and a staff secretary . . . can derogate from the high probability that they will be no answer to the main question: $E$ pluribus unum?

This is a good mind at its best, but the author could not help but wish that Finer had not plead so valiantly for a greater plurality in running the national executive branch and then somewhat incongruously (although the situations are by no means comparable) criticized the Hoover Commission itself for a lack of a single executive head and an oversized membership. ${ }^{62}$

\section{ConClusions}

The plans for staffing the President as reviewed in this article reveal the scope of thinking upon the great issues of how best to remodel the administrative structure at the apex of the national executive institution in order better to equip it to meet effectively its ever-increasing volume of responsibilities. Among the plans studied, there was widespread agreement that a secretariat to the President headed by some sort of staff secretary is definitely desirable. There were, however, wide differences of opinion as to the functions and powers which this key presidential aide should exercise. It is of historical interest that plans for an executive secretary date from rg20.

Many plans called for a limited group of cabinet committees, staffed by a secretariat located in the Executive Office, in hopes that rigid jurisdictional lines of authority and programming could thus be broken down. Yet, there was no expressed majority opinion either as to who should constitute these functional groups or what their proper relationships should be to permanent staff units already in the Office. Neither was there any overwhelming consensus on the question of whether these functional collectivities should be precisely determined by presidential decree or congressional statute or simply recognized as ad hoc temporary, and highly flexible committees. There was, however, rather marked similarity among the plans in respect to the selection of the subject matter areas to be studied and coordinated by these groups. What we have in fact in EXOP today are refinements and adjustments of the central theme that ran through most of these proposed staffing systems.

While there is unanimous agreement among the drafters of these plans that the President's office imposes more severe strains than any other office in the world and that he cannot possibly do all of the work as he should without efficient staff facilities, staff specialists in the nineteen-fifties in the latter part of the Eisenhower administration began to claim that not only can staff services be so organized as to enable a busy President shouldering terrific responsibilities to make the right de-

\footnotetext{
${ }^{e 2}$ For the author's own proposal for a reorganized Executive Office of the President, see Edwand H. Hobis, Behind the President (1954). Another study that students of this subject might well want to examine is a special committee report, B. P. Nash, Staffing the Presidency (National Planning Ass'n Pamphlet No. 80, I952).
} 
cisions the great majority of the time, but also that staff services can actually be so designed and managed as to relieve the pressures on the chief executive to the extent that a weakened President in a physical sense might continue in office as a "strong" President in the political sense. Is the age of automation to produce a push-button brand of presidential leadership? If so, what are the implications of this new kind of presidential office for our constitutional system? 